\title{
PUBLIC PERCEPTION OF THE SOCIAL AND ECOLOGICAL STATUS OF LAKE CEELIJE
}

\author{
Maja Vujčić Trkulja*, \\ Lidija Amidžić, \\ Miloš Vasić
}

Singidunum University, Belgrade, Serbia

\begin{abstract}
:
The lack of environmental awareness and social culture globally has become one of the important determinants of sustainable development problems that also affect industries in the field of environmental protection and tourism. This paper aims to draw more attention to a socio-ecological overview of Lake Ćelije and its potential for ecotourism as one of the ecosystem services by assessing the perception of the local community. 122 respondents were invited to take part in the survey by filling in an online questionnaire using social networks. The results of the survey show that the local community recognized that the water quality of Lake Ćelije with its surroundings was threatened by pollution generating from agricultural activities and landfills near the lake. However, the results indicate that Lake Ćelije with its environmental qualities has great potential for the development of ecotourism through cooperation with the local community and education of people, especially addressing these concerns to local management structures and policymakers.
\end{abstract}

Keywords:

environmental pollution, local community, eco-tourism, Lake Ćelije, Serbia.

\section{INTRODUCTION}

Socio-environmental issues have become important determinants at the global level and therefore our society has not been left out. The reason for the emergence of social and environmental problems concerns the lack of environmental awareness, environmental conscience, and environmental culture. Although modern science pays more and more attention to this problem, and the problem itself has become the focus of interest of the scientific, professional, and other public spheres (Marković, 2005), the question of social and ecological awareness dates back to the $60 \mathrm{~s}$ and it still hasn't subsided. On the contrary, its intensity has become progressive, drawing attention to the increasingly present ecological crisis. From the perspective of the present moment, the development of social ecology is stimulated by the need to raise ecological awareness, enhance improvement, and scientific management of the environment (Koković, 1996; Vukićević, 2005). Therefore, this paper aims to present a socio-ecological overview of Lake Ćelije by assessing the perception of local population.
Correspondence:

Maja Vujčić Trkulja

e-mail:

mvujcictrkulja@singidunum.ac.rs 
As presented in Fig. 1, Lake Celije is located on the territory of the Republic of Serbia, more precisely, it belongs to the Rasina district. It stretches in a north-south direction and belongs to the municipalities of Brus and Kruševac. Water quality of the lake is determined by the natural characteristics of catchment water area (Maljević et al., 1999). Still, water quality is highly impacted by the industrial and municipal wastewaters originating from two cities, the city of Brus, which is located on the left bank of the Rasina river, and the city of Blace located on the right bank of the Blatašnica river (Drenovac et al., 2011). Taking everything into account, a special focus in this paper is placed on the examination of knowledge and attitude of the local community about the current status of the lake regarding the lake's environment, education of the population, improvement of human resources, and development of tourism as the ecosystem service. This topic is of great concern because it deals with the problem of pollution of the lake itself and its surroundings and the human role in these negative effects on the environment.

\section{LITERATURE REVIEW}

Mankind is inseparably connected with nature and only by respecting the value of the natural environment and balanced use of natural resources can the development of societies in many countries of the world be enabled (Jaszczak et al., 2020). The emergence of social ecology issues was also initiated by the findings that the ecological balance is disturbed and this occurs not only as a conflict of an individual or group with its natural environment but also as a consequence of a complex relationship between natural entities, technical sphere and social systems (Gunderson and Holling, 2002, Marković, 2005; Marzluff, 2008; McDonnell and Hahs, 2008). Undoubtedly, the urbanisation affected land-use change which correlated with the intensive exploitation of ecological resources (Barthel et al., 2010). The main concerns regarding urbanisation involve pollution, habitat degradation, and high extinction rates for native species with lasting consequences not only for biodiversity but for human health and quality of life as well (Stein et al., 2000; Marzluff, 2008). This paper is based on the fact that untreated wastewater originating from the territories of Brus and Blace municipalities, endangers the quality of the water of Ćelije accumulation, which is the source of the supply of drinking water to the city of Kruševac and the surrounding districts (Ćirić et al., 2011). Subsequently, different researches have shown that the initiatives organized by the local community can mitigate the urban living stressors on the environment and people's well-being through constructive and innovative use of public perception and education with the promotion of ecosystem services (Dennis and James, 2016). The UK government's experience in social ecology challenge has also been promoted as a method of "cultivating" local participation and preserving ecological awareness as well as contributing to the importance of blue and green infrastructure in urban landscapes (Pudup, 2008; Barthel et al., 2010; Defra, 2011). Stakeholder participation is also an important factor in environmental management which could support the development and improvement of socio-ecological systems, indicating the diverse examples of community-ecological participation that acknowledge great potential regarding the adjustable co-management of ecosystems in urban areas (Gunderson and Holling, 2002; Colding and Barthel, 2013). 


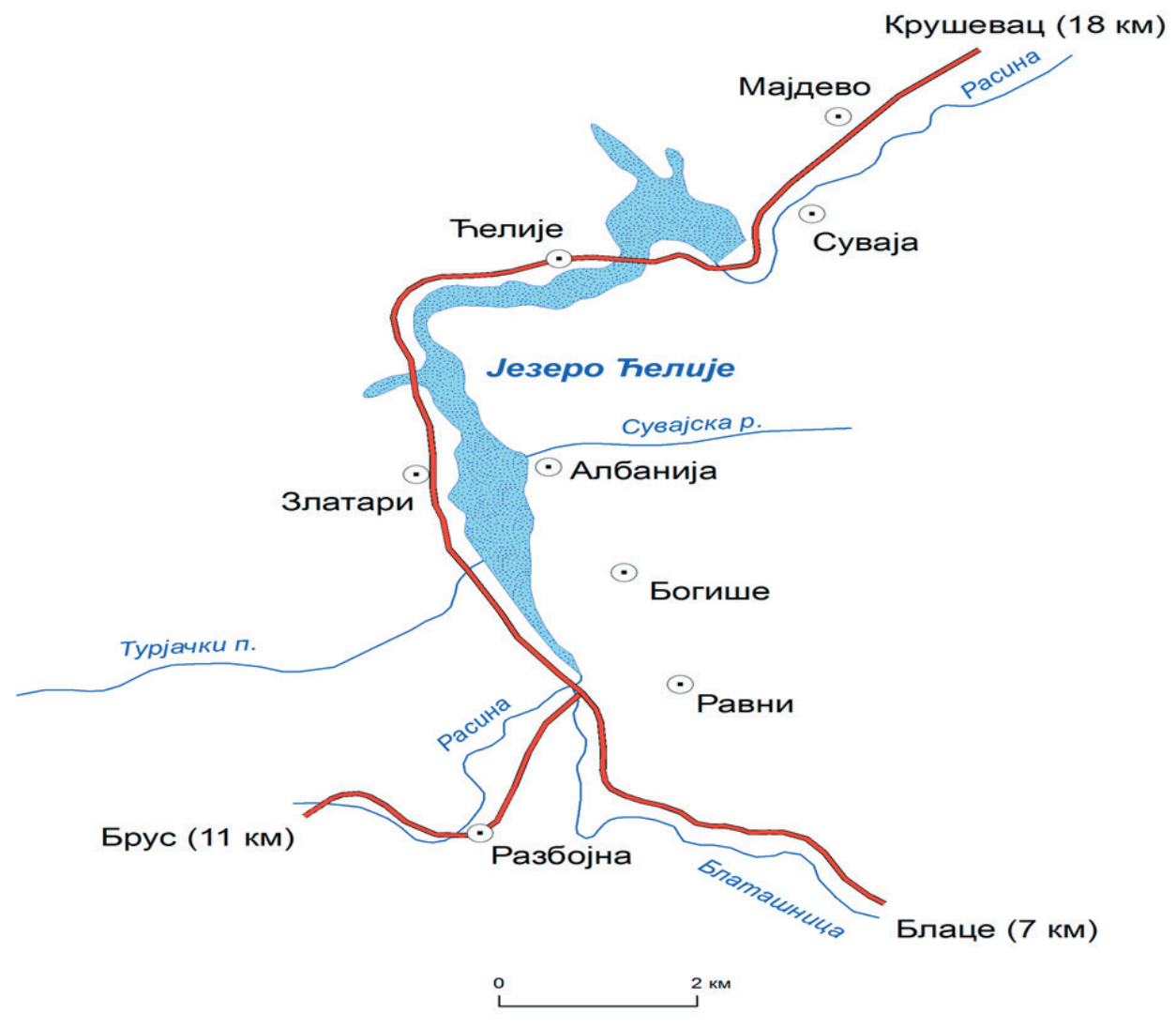

Source: (Retrieved September 18, 2020, from https://commons.wikimedia.org/wiki/File:Map\%C4\%86elijeJPG.png)

\section{METHODOLOGY}

In order to examine the local community perception, an open-ended survey was conducted. The purpose of the survey was to discover whether the residents who live in the surrounding areas are informed about the current social and environmental status of Lake Celije. The respondents were asked to take part in the survey by filling in an online questionnaire. The survey consisted of a combination of different types of questions that were related to the following: socio-ecological status of the lake, rating the environmental qualities by their use, and the effects that they have on social benefits of respondents; all of which were recorded on a 5-step Likert scale. Combining various types of questions can help with investigating different dimensions of the respondent's beliefs and particularly with confirming that precise information was obtained (Tomićević, 2005). 122 respondents were interviewed using social networks. All respondents were Serbian residents and had an equal gender distribution with $50 \%$ being female respondents and $50 \%$ being male respondents. According to the socio-demographic variables, more than half of the respondents (58\%) had higher education and $82.8 \%$ of all respondents had an age range between 20-39 years. The results of the survey were analysed using the basic descriptive statistics that involved means and percentages.

\section{RESULTS}

According to the results presented in Fig. 2, local community recognised that the water quality of Lake Celije with its surroundings was threatened by pollution. More than $70 \%$ of respondents indicate that the use of pesticides originating from agricultural activities near the lake affects water quality in the lake. 
Additionally, around $52 \%$ of respondents disagree with the statement that the problem of waste and landfills near the lake is adequately solved. Opinions are divided when it comes to water quality in the lake. However, most respondents $(52 \%)$ consider that water is not safe for drinking.

Figure 2. The perception of local community on the environmental qualities of Lake Celije by their use and current state

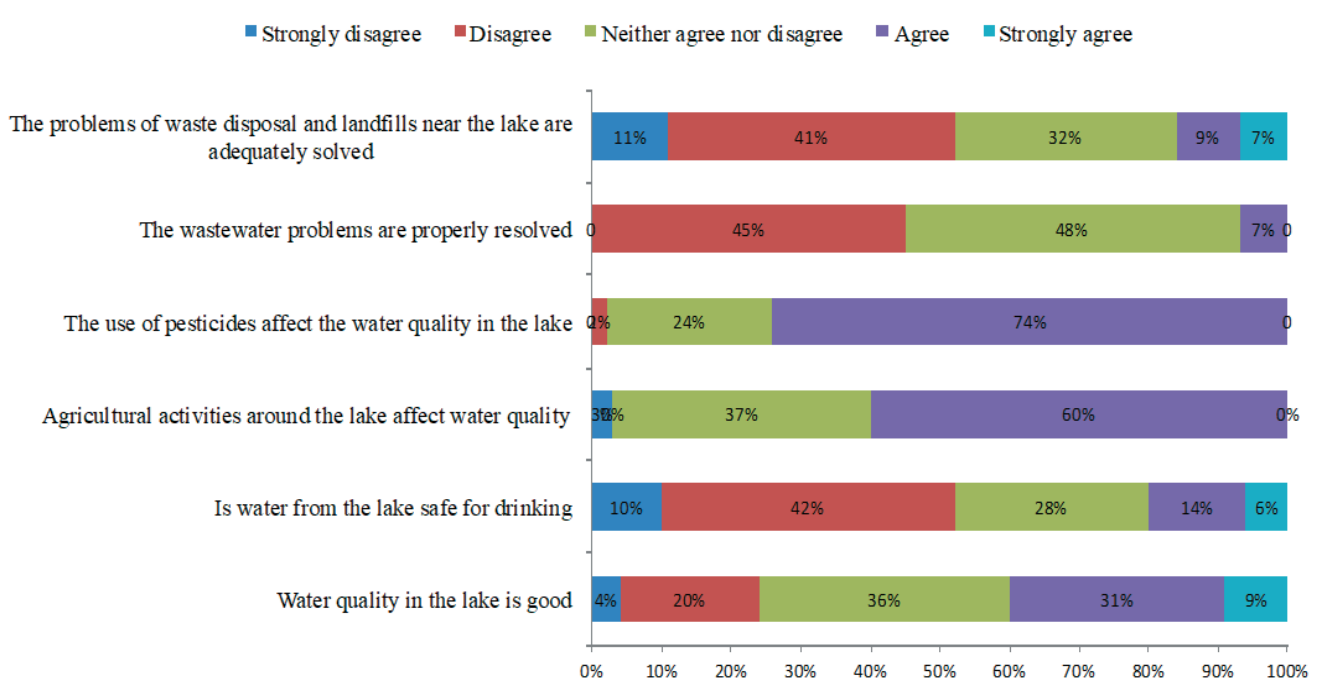

According to the results in Fig. 3, the perception of local community regarding the ecological status of Lake Celije and its potential for ecotourism is not clear enough. The respondents' perception of different activities performed on the lake such as fishing and using motor vehicles can be perceived as positive. $57 \%$ of respondents support fishing on the lake, but they stay mostly restrained on the use of motor vehicles on Lake Celije. On the other hand, people's perception towards ecological awareness and commitment to organized actions of cleaning the lake can be perceived as rather vague. $50 \%$ of respondents are not determined regarding the issue of environmental awareness and their role in preserving the lake's surrounding and enhancing its potential for eco-tourism development. Still, the results show that $26 \%$ of respondents are informed of activities related to the maintenance of the lake and can see their role in such projects. When it comes to protection and management of Lake Ćelije $60 \%$ of the respondents consider that local management structures and policymakers are not engaged enough in the protection of the lake and investigation of its touristic and eco-touristic potential.

Figure 3. The perception of local community on the environmental qualities of Lake Celije and the effects they have on social benefits

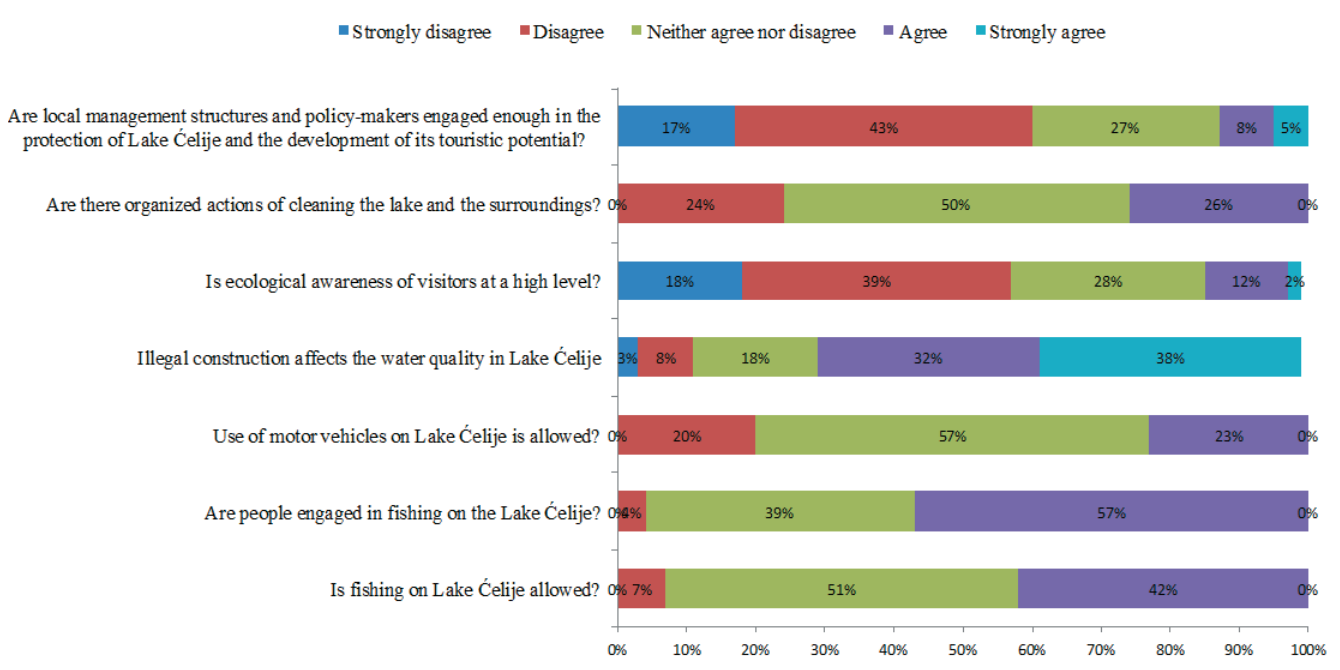




\section{CONCLUSIONS AND DISCUSSION}

When it comes to supply and water quality of Lake Celije the situation is not at a satisfactory level. It is deeply affecting the territory of cities and districts surrounding the lake such as Kruševac, Brus, and Rasina district. Regarding the supply of drinking water, the biggest problems are: uncoordinated management of this important natural resource, unintended water consumption, and inadequate protection of springs. One of the key reasons is a significant difference between the basic needs of the local community and the real investments by local governments and policymakers. These concerns are also globally recognised and through them the role of societal choices and taking action in the preservation of ecosystem services and conservation of biodiversity is acknowledged (CBD, 2004; MEA, 2005). Due to that, local perception of diverse environmental and societal challenges have therefore received growing attention in supporting the potential of Lake Celije and the development of different industry sectors mainly tourism and ecotourism. According to the European Commission report (2015), there has been increasing interest and awareness regarding the value of natural resources and their use as means to increase cost-effectiveness and to ensure positive responses in local business communities (Cecchi, 2015). The results in this paper indicate that the socio-ecological status of Lake Celije is vulnerable but the public perception of the lake's environmental characteristics can be acknowledged as a great benefit for both the local community and the whole region. The local community strongly encourages local management structures and policymakers to engage in the activities that involve the protection of the lake's environment and water resources and to promote better sustainable use of the lake's resources by investing in its touristic and eco-touristic potentials.

\section{REFERENCES}

Barthel, S., Folke, C., Colding, J. (2010). Social-ecological memory in urban gardens: retaining the capacity for management of ecosystem services. Global Environ. Change 20 (2), 255-265.

DOI: doi.org/10.1016/j.gloenvcha.2010.01.001

CBD, (2004). The Ecosystem Approach (CBD Guidelines). Secretariat of the Convention on Biological Diversity, Montreal.

Cecchi, C. (2015). Towards an EU research and innovation policy agenda for nature-based solutions \& re-naturing cities. Final report of the Horizon 2020 expert group on nature-based solutions and re-naturing cities Luxembourg: Publication Office of the European Union.

Colding, J., Barthel, S. (2013). The potential of 'Urban Green Commons' in the resilience building of cities. Ecol. Econ. 86, 156-166. DOI: 10.1016/j.ecolecon.2012.10.016

Ćirić, S., Grašić, S., Vasiljević, B., Petrović, O. (2011). Bacterial load and representation of bacteria morphotypes in catchment basin of Lake Ćelije. The $40^{\text {th }}$ Annual Conference of the Serbian Water Pollution Control Society "Water 2011", Conference Proceedings, pp. 163-168. UDK: 579.68 : 627.81 (497.11)

Defra, 2011. The Natural Choice: Securing the Value of Nature. Defra, London.

Dennis, M., James, P. (2016). User participation in urban green commons: Exploring the links between access, voluntarism, biodiversity and well-being. Urban Forestry \& Urban Greening, 15, 22-31.

DOI: 10.1016/j.ufug.2015.11.009

Drenovac, O, Amidžić, L., Babović, N. (2011). Environmental status of the Ćelije reservoir. The $40^{\text {th }}$ Annual Conference of the Serbian Water Pollution Control Society "Water 2011", Conference Proceedings, pp. 157-162. UDK: $579.68: 627.81$ (497.11)

Gunderson, L., Holling, C. (2002). Panarchy: Understanding Transformations in Human and Natural Systems. Island Press, Washington, DC.

Jaszczak, A., Kristianova, K., Wasilewska, O., Dunisijevic-Bojovic, D. (2020). Concepts of "biophilia" and "livability" in the context of social perception of public space in cities. Article in Space \& Form, June 2020 DOI:10.21005/ pif.2020.42.C-02

Koković, D. (1996). Sociologija religije i obrazovanja, Učiteljski fakultet, Sombor. (In Serbian)

Maljević, E., Karadžić, V., Vasiljević, M. (1999). Kvalitetr vode akumulacije Ćelije u zimskom periodu, Konferencija „Zaštita voda 1999“, Soko Banja, Zbornik radova. Jugoslovensko društvo za zaštitu voda, Beograd. (In Serbian) 
Marković, Ž.D. (2005). Socijalna ekologija, Zavod za udžbenike i nastavna sredstva, Beograd. (In Serbian) Marzluff, J. (2008). Urban Ecology. Springer Science and Business Media, New York, NY.

McDonnell, M., Hahs, A. (2008). The use of gradient analysis studies in advancing our understanding of the ecology of urbanizing landscapes: current status and future directions. Landscape Ecol. 23, 1143-1155. DOI: 10.1007/ s10980-008-9253-4

MEA, (2005). Ecosystems and Human Well-being: Health Synthesis. Island Press, Washington, DC.

Pudup, M. (2008). It takes a garden: cultivating citizen-subjects in organized garden projects. Geoforum 39 (3), 1228-1240. DOI: 10.1016/j.geoforum.2007.06.012

Stein, B., Kutner, L., Adams, J. (2000). Precious Heritage. Oxford University Press, Oxford.

Tomićević, J. (2005). Towards Participatory Management: Linking People, Resources and Management. A Socio-Economic Study of Tara National Park. Institut für Landespflege der Albert-Ludwigs-Universität Freiburg, Freiburg, Germany.

Vukićević, S. (1996). Ideal i stvarnost eko menadžmenta, Služba zaštite životne sredine Opština Nikšić, Nikšić. (In Serbian) 